\title{
Dok. 2. \\ Konkluzje z posiedzenia Rady Europejskiej w Brukseli 28-29 października 2010 r.
}

\author{
RADA EUROPEJSKA Bruksela, 29 października 2010 r. \\ EUCO 25/10 CO EUR 18 CONCL 4 PISMO PRZEWODNIE Od: Sekretariat General- \\ ny Rady Do: Delegacje \\ Dotyczy: RADA EUROPEJSKA 28-29 PAŹDZIERNIKA 2010 R. \\ KONKLUZJE \\ W załączniku delegacje otrzymują konkluzje Rady Europejskiej (z obrad w dniach \\ 28-29 października 2010 r.).
}

Aby zając się wyzwaniami, które ujawnił niedawny kryzys finansowy, potrzebna jest fundamentalna zmiana europejskiego zarządzania gospodarczego. W tym celu Rada Europejska zatwierdziła sprawozdanie grupy zadaniowej ds. zarządzania gospodarczego. Jego wdrożenie będzie stanowić ważny krok w kierunku zapewnienia mocniejszego gospodarczego filara unii gospodarczej i walutowej: poprawi się dyscyplina fiskalna, nadzór ekonomiczny zostanie rozszerzony, a koordynacja - pogłębiona. Sprawozdanie zawiera również wytyczne w sprawie tworzenia solidnych ram zarządzania w sytuacjach kryzysowych i silniejszych instytucji. Rada Europejska uzgodniła dalsze postępowanie po zakończeniu prac grupy zadaniowej. W następstwie dyskusji w dniu 16 września 2010 r. Rada Europejska przeprowadziła także wymianę poglądów z myślą o przygotowaniach do szczytu G20 w Seulu oraz do konferencji w Cancún w sprawie zmiany klimatu, a także do szczytów ze Stanami Zjednoczonymi, Rosją i Ukrainą.

\section{GRUPA ZADANIOWA DS. ZARZĄDZANIA GOSPODARCZEGO}

1. Rada Europejska zatwierdza sprawozdanie grupy zadaniowej ds. zarządzania gospodarczego. Jego wdrożenie pozwoli nam na poprawę dyscypliny fiskalnej, rozszerzenie nadzoru ekonomicznego, pogłębienie koordynacji oraz stworzenie solidnych ram zarządzania w sytuacjach kryzysowych, a także silniejszych instytucji. Rada Europejska wzywa do przyspieszonego działania w zakresie przyjmowania prawodawstwa wtórnego potrzebnego do realizacji wielu z zaleceń grupy. Celem Rady i Parlamentu Europejskiego jest osiągnięcie do lata 2011 roku porozumienia co do wniosków ustawodawczych Komisji, z uwzględnieniem faktu, że sprawozdanie grupy zadaniowej nie obejmuje wszystkich zagadnień, których dotyczą te wnioski, i na odwrót. Porozumienie to zapewni jak najszybszą skuteczną realizację nowych ustaleń w zakresie nadzoru. W jej wyniku znacznie wzmocniony zostanie gospodarczy filar unii gospodarczej i walutowej, wzrośnie poziom zaufania, co w konsekwencji przyczyni się do trwałego wzrostu gospodarczego, zatrudnienia i konkurencyjności. Rada Europejska zwraca się do Rady, aby przyspieszyła prace nad sprawdzeniem, jak wpływ reform emerytalnych jest uwzględniany w realizacji paktu stabilności i wzrostu, i aby wyniki przedstawiła 
Radzie Europejskiej w grudniu. Z uwagi na znaczenie systemowych reform emerytalnych należy zapewnić równe warunki realizowania paktu.

2. W następstwie sprawozdania grupy zadaniowej i w celu zapewnienia zrównoważonego i trwałego wzrostu, szefowie państw i rządów zgadzają się co do tego, że państwa członkowskie powinny utworzyć stały mechanizm kryzysowy służący ochronie stabilności finansowej całej strefy euro, i zwracają się do przewodniczącego Rady Europejskiej o podjęcie konsultacji z członkami Rady Europejskiej w sprawie nieznacznej zmiany Traktatu, która byłaby w tym celu konieczna, bez zmiany art. 125 TFUE (klauzula o nieprzejmowaniu zobowiązań). Rada Europejska z zadowoleniem przyjmuje fakt, że Komisja w ścisłej konsultacji z przewodniczącym Rady Europejskiej zamierza przeprowadzić prace przygotowawcze nad ogólnymi cechami przyszłego nowego mechanizmu, między innymi dotyczące roli sektora prywatnego, roli MFW oraz bardzo restrykcyjnych warunków, na których te programy powinny działać. Rada Europejska powróci do tej kwestii podczas swojego grudniowego posiedzenia, po to by podjąć ostateczną decyzję zarówno co do ogólnego kształtu mechanizmu kryzysowego, jak i nieznacznej zmiany Traktatu; celem byłoby ratyfikowanie wszelkich zmian najpóźniej do połowy 2013 roku. Przewodniczący Rady Europejskiej zamierza następnie $\mathrm{w}$ porozumieniu z państwami członkowskimi przeanalizować kwestię prawa członków strefy euro do uczestniczenia $\mathrm{w}$ podejmowaniu decyzji $\mathrm{w}$ ramach procedur związanych z UGW w przypadku trwałego zagrożenia stabilności całej strefy euro.

3. Szefowie państw i rządów podkreślili, że w momencie kiedy w Unii Europejskiej wzmacniana jest dyscyplina fiskalna, ważne jest, by budżet Unii Europejskiej i najbliższe wieloletnie ramy finansowe odzwierciedlały wysiłki konsolidacyjne państw członkowskich mające na celu sprowadzenie deficytu i długu na bardziej zrównoważoną ścieżkę. Przy poszanowaniu roli różnych instytucji i uwzględnieniu konieczności osiągnięcia europejskich celów Rada Europejska omówi na następnym posiedzeniu kwestię tego, jak dopilnować, by wydatkowanie środków na szczeblu europejskim odpowiednio przyczyniło się do tych działań.

\section{SZCZYT G20 W SEULU}

4. Światowa gospodarka wychodzi z kryzysu. Wciąż pozostają jednak pewne problemy, które nieprzerwanie wymagają uwagi na szczeblu globalnym; są to: zagrożenia dla stabilności finansowej, niepełna naprawa systemu finansowego, wysokie bezrobocie, niestabilność światowych cen surowców oraz ponowne wystapienie zakłóceń równowagi makroekonomicznej na świecie. Rada Europejska potwierdziła kierunki polityki uzgodnione przez Radę i omówiła priorytety, które będą promowane na szczycie w Seulu przez przedstawicieli UE i państw członkowskich UE należących do grupy G20. Szczyt ten musi sformułować ambitne przesłanie wzywające do konkretnej i terminowej realizacji środków uzgodnionych w deklaracji dotyczącej ram silnego, trwałego i zrównoważonego wzrostu, zwłaszcza jeżeli chodzi o plany konsolidacji fiskalnej, finansową reformę regulacyjną, spójność społeczną, tworzenie miejsc pracy oraz potrzebę dalszych reform strukturalnych. Szczególnej uwagi wymaga także kwestia przywrócenia równowagi wzrostu światowego. Unia Europejska oczekuje, że na szczycie w Seulu potwierdzone zostanie porozumienie z Bazylei, które jest ważnym 
krokiem w kierunku wzmocnienia światowej stabilności finansowej. Unia Europejska podkreśla potrzebę zachowania otwartych rynków, nadania tempa negocjacjom dauhańskim oraz przyjęcia agendy rozwoju ukierunkowanej na wzrost. Podkreśla, że konieczne jest unikanie wszelkich form protekcjonizmu oraz manipulowania kursami walutowymi w celu uzyskania krótkoterminowej przewagi konkurencyjnej.

5. Dzięki porozumieniu osiagniętemu na posiedzeniu ministerialnym grupy G20 w dniu 23 października 2010 r. w sprawie reformy Międzynarodowego Funduszu Walutowego zwiększy się skuteczność, wiarygodność i legitymizacja tego funduszu i będzie on mógł wypełnić swe zadanie wspierania działania międzynarodowego systemu walutowego i finansowego. Reformę systemu kwot oraz szerszą reformę zarządzania należy zrealizować w ramach jednego kompleksowego pakietu objętego wspólnym kalendarzem.

6. Konieczne są dalsze prace - zarówno na szczeblu międzynarodowym, jak i wewnętrznym - w zakresie opłat i podatków nakładanych na instytucje finansowe. Zgodnie ze sprawozdaniem Rady należy lepiej skoordynować różne obowiązujące systemy takich opłat, aby unikać podwójnego obciążania. Zachęca się Radę, by złożyła ponownie sprawozdanie Radzie Europejskiej w grudniu 2010 roku. Należy również przeanalizować różne warianty opodatkowania sektora finansowego, jak również wzorcowe rozwiązania utrudniające korzystanie z rajów podatkowych i uchylanie się od opodatkowania.

\section{KONFERENCJA W CANCÚN W SPRAWIE ZMIANY KLIMATU}

7. Potrzeba postępów w rozwiązywaniu problemu zmiany klimatu staje się coraz pilniejsza. Dlatego ważne jest, by konferencja w Cancún stała się istotnym etapem opierającym się na protokole $z$ Kioto i otwierającym drogę do globalnych i kompleksowych prawnie wiążących ram, które uwzględnią wskazówki polityczne zawarte w porozumieniu kopenhaskim. Niezwykle istotne jest, by Unia Europejska i jej państwa członkowskie nadal odgrywały konstruktywną rolę i zajmowały jednolite stanowisko. Rada Europejska zatwierdza konkluzje Rady z dnia 14 października 2010 r. w sprawie przygotowań do konferencji w Cancún i potwierdza gotowość Unii Europejskiej, by rozważyć przyjęcie drugiego okresu zobowiązań w ramach protokołu z Kioto, pod warunkiem że spełnione zostaną warunki określone w tych konkluzjach. Unia Europejska przekaże w Cancún kompleksowe i przejrzyste sprawozdanie na temat realizacji jej zobowiązania w sprawie szybkiego finansowania, a kolejne takie sprawozdania będzie przekazywać co roku; podkreśli także znaczenie dalszego zwiększania przejrzystości finansowania działań związanych ze zmianą klimatu. Unia Europejska ponownie oceni sytuację po konferencji w Cancún, w tym przeanalizuje możliwości przyjęcia docelowej wielkości redukcji emisji gazów cieplarnianych przekraczającej zakładane $20 \%$, tak by przygotować się do reagowania na przebieg międzynarodowych negocjacji w sprawie klimatu; Rada proszona jest o złożenie sprawozdania w tej kwestii do wiosny 2011 roku. Dążąc do międzynarodowego porozumienia, UE będzie równolegle pracować nad bardziej zróżnicowanym podejściem do nawiązywania współpracy z kluczowymi partnerami w obszarach będących przedmiotem wspólnego zainteresowania, w których możliwa jest pomoc w redukcji emisji. W tym względzie UE popiera regionalne inicjatywy (takie jak niedawno podjęta śródziemnomorska inicjatywa dotycząca 
zmiany klimatu) będące odpowiedzią na zmianę klimatu i propagujące ekologiczny wzrost.

\section{SZCZYTY Z PAŃSTWAMI TRZECIMI}

8. Zgodnie z konkluzjami z września 2010 roku Rada Europejska omówiła kluczowe postulaty polityczne, które przewodniczący Rady Europejskiej i przewodniczący Komisji będą promować na nadchodzących szczytach ze Stanami Zjednoczonymi, Rosją, Ukraina, Indiami i Afryką. Przy okazji Rady Europejskiej odbył się szczyt społeczny, który po zapoznaniu się ze sprawozdaniem końcowym grupy zadaniowej skoncentrował się na zarządzaniu gospodarczym, w świetle konkluzji przyjętych przez Radę (EPSCO) w dniu 21 października $2010 \mathrm{r}$. 